\title{
Is Psychological Stress a Possible Risk Factor for Periodontal Disease? A Systematic Review
}

Hassan S Halawany ${ }^{1,2}$, Nimmi B Abraham ${ }^{2}$, Vimal Jacob ${ }^{2}$, Mohammad D. Al Amri ${ }^{3}$, Shankargouda Patil ${ }^{4}$ and Sukumaran Anil

${ }^{1}$ Department of Periodontics and Community Dentistry, College of Dentistry, King Saud University, Riyadh, Saudi Arabia

${ }^{2}$ Dental Caries Research Chair, College of Dentistry, King Saud University, Riyadh, Saudi Arabia

${ }^{3}$ Department of Prosthetic Dental Sciences, College of Dentistry, King Saud University, Riyadh, Saudi Arabia

${ }^{4}$ Department of Oral Pathology and Microbiology, Faculty of Dental Sciences, M. S. Ramaiah University of Applied Sciences, Bangalore, Karnataka, India

"Corresponding author: Sukumaran Anil, Department of Periodontics and Community Dentistry, College of Dentistry, King Saud University, P.O. Box 60169, Riyadh 11545, Saudi Arabia, Tel: +966500197223; E mail: drsanil@gmail.com

Received Date: November 22, 2014, Accepted Date: December 17, 2014, Published Date: December 24, 2014

Copyright: ( 2015 , Halawany et al., This is an open-access article distributed under the terms of the Creative Commons Attribution License, which permits unrestricted use, distribution, and reproduction in any medium, provided the original author and source are credited.

\begin{abstract}
Background: Observations from several epidemiologic and clinical studies suggest that psychological stress has a role in the etiology and progression of periodontal diseases (PD). The aim of the present study was to systematically analyze the influence of stress on periodontal disease reported in various case control, cross sectional and prospective clinical trials. The focused question analyzed in this systematic review was whether there is sufficient evidence to consider stress as risk factor for periodontal disease.
\end{abstract}

Methods: The literature search for relevant articles was conducted using PubMed, Ovid Medline, EMBASE, the Cochrane Database of Systematic Reviews, and Google Scholar. Additionally, reference lists of original and review articles were searched. The keywords and combinations of keywords used were "stress," "periodontal disease," and "psychosocial disorders." Studies published between May 1, 2006 and January 1, 2014 were considered in this review. Articles in English; human studies; published in dental and medical journals, all age groups were included.

Results: Of the 43 studies searched for relevancy, 25 articles were excluded, generally because they were reviews and articles related to biomarkers of stress and periodontal disease; a few studies did not have the exposure or outcomes defined, as required for this review, and two were based on mental disorder and posttraumatic syndrome patients. As a result, 18 articles were included in this systematic review. Analysis of the 12 cross sectional studies showed that except one study all the other studies showed a positive correlation between stress and periodontal disease. All the three case control studies included showed a positive correlation between stress and PD. Out of the 2 prospective clinical studies, both showed a relationship including a negative response to periodontal therapy.

Conclusions: The majority of studies showed a positive relationship between stress and periodontal disease. The diverse parameters used in assessment of stress and PD, fewer numbers of patients were the major drawbacks of the studies. Further well designed and more focused studies are necessary to confirm the role of stress as a risk factor for periodontal disease.

Keywords: Periodontal diseases; Stress; Psychological distress; Systematic review; Oral health

\section{Introduction}

Oral health is an integral component of general health and wellbeing of an individual. Knowledge about the association between periodontal disease and systemic health is growing rapidly [1]. Periodontitis is a chronic inflammatory disease characterized by episodes of active destruction to pronounced inflammatory infiltration, attachment loss, and alveolar bone loss. The mechanisms underlying this destructive process involve both direct tissue damage resulting from bacterial products and indirect damage through bacterial induction of the host inflammatory and immune responses. Systemic diseases and conditions such as diabetes mellitus, aging, tobacco use, have been identified as important risk factors for periodontitis [2,3]. Psychosocial stress is thought to play an important role in the etiology and progression of periodontal diseases, and the outcome of treatment [4,5]. The relationship between periodontitis and several dimensions of psychosocial distress such as stress, depression, anxiety, life events and poor coping reactions has attracted considerable attention from several groups of researchers during the last three decades [6-9]. A review showed a strong relationship between periodontal diseases and psychological factors such as stress, distress, anxiety, depression and loneliness [9]. The factors responsible for such an association could be due to psychologically induced modulation of the immune system, leading to increased blood levels of adrenocorticotropic hormones, alteration of crevicular cytokine levels, depressed polymorphnuclear leukocyte chemotaxis and phagocytosis, reduced proliferation of lymphocytes, changes in blood circulation and healing, modifications of the salivary flow and its components and endocrine changes leading to immunosuppression $[10,11]$.

The behavioral mechanism of stress could also have an indirect effect on periodontal health through the life style changes such as smoking and drinking, an unhealthy diet and neglect of oral hygiene, 
leading to decreased host response and an increased risk for severe periodontal disease [12,13]. Various clinical observations and epidemiological studies indicate that there is a relationship between experiences of negative life events and the development and progression of periodontal disease $[14,15]$. Studies have shown that the effects of adverse life circumstances such as financial strain [13], domestic and health problems, spousal bereavement and academic stress [16] might contribute to the diminution of general health, facilitating bacterial invasion resulting from poor oral hygiene and periodontal destruction.

Several clinical studies have investigated the possible relationship between psychological stress and periodontitis and have proposed a biological pathway of action and a behavioral pathway of action $[13,17]$. The biological mechanism emphasizes the mechanism by which stress and depression could reduce immune system function and cause chronic inflammation. As a result of stressful events, stimulation of the hypothalamus-pituitary-adrenal (HPA) axis leads to the secretion of corticotropin-releasing hormone from the pituitary gland and cortisol, a glucocorticoid hormone, from the adrenal cortex. This action is capable of reducing immune responses by inhibiting the functions of lymphocytes, macrophages and monocytes, thereby increasing the susceptibility of individuals to infection. The biological mechanism involves the autonomous nervous system (ANS) which, when stimulated by adrenergic receptors, leads to secretion of catecholamines (adrenalin/noradrenalin) (CAs), neuropeptides such as substance $\mathrm{P}(\mathrm{SP})$ [18] and chromogranin $\mathrm{A}(\mathrm{CgA})$ by the adrenal medulla, thereby indirectly provoking periodontal tissue breakdown. Catecholamines regulate the immune response by stimulation of immune cell propagation and activity $[19,20]$, whereas CgA have antimicrobial effects [21]. The autonomous nervous system acts on the salivary glands during stress by secreting enzymes such as salivary alpha-amylase (sAA), which acts by neutralizing and preventing pathogens from entering the body via the mucosal surfaces and inhibiting the adherence and growth of bacteria in the oral cavity $[22,23]$. Increased production of pro-inflammatory cytokines [24] and interleukin-6 [25] was reported in response to psychological stress, which leads to sustained inflammatory destruction within the periodontium.

The association of stress with periodontal disease is difficult to prove as there are many co-founding factors influencing the incidence and severity of periodontal disease. Psychological factors have been shown to be associated with the incidence and severity of periodontitis, but the mechanism of action is still unknown $[9,26]$. Hence this systematic analysis of the available literature on role of stress on periodontal disease is carried to identify and compile the available evidence to show the association.

\section{Materials and Methods}

\section{Structural development}

The structure of this study was developed to update the focus question, and it examines the following areas of the review method: the search strategy, inclusion criteria/exclusion criteria, data extraction, summary of evidence, comparison of outcomes and quality assessment by two reviewers, conclusions and evidence based recommendations.

\section{Search strategy}

The literature search for relevant articles was conducted using PubMed, Ovid Medline, EMBASE, EBSCO, the Cochrane Database of Systematic Reviews, and Google Scholar, beginning in November 2013. Reference lists of original and review articles were searched. The following keywords and combinations of keywords were used: "periodontal disease" or "periodontitis" or "stress" (psychological, mental or emotional) or "stress markers" or "psychological factors" or "psychosocial factors". The last search was conducted on January 31, 2014.

\section{Inclusion/exclusion criteria}

The searches were limited by date (May 2006 to January 2014) and to articles in English regarding human studies in dental and medical journals; the participants included all age groups, irrespective of gender. Our search included longitudinal studies, case control studies, cross-sectional studies and prospective clinical trials. All of the studies had criteria to define periodontal disease (bleeding on probing (BOP), probing depth $(\mathrm{PD})$, attachment loss $(\mathrm{AL})$, alveolar bone loss (ABL), recession level(REC), remaining periodontal support and missing teeth) and to establish stress (stress evaluation questionnaires, psychometric scales to measure stress such as the salivary cortisol level). The exclusion criteria were languages other than English, animal studies, review articles, studies presented in the form of abstracts of scientific conferences and other unpublished reports. Studies involving participants with psychiatric diagnosis or psychological disorders were excluded.

\section{Appraisal of the quality of the studies}

The quality assessment was derived from the National Health Service Centre for Reviews and Dissemination [27]. The quality of the studies was evaluated on the criteria used to define periodontal disease and stress. The quality of the adjustment for confounding variables that could interfere with the course of the periodontal disease was evaluated by randomization, stratification, restriction, calibration and/or matching. These characteristics were classified as present or absent, which is in agreement with Peruzzo et al. [9]. The specificity of the data indicating the randomization technique and the calibration value was required to be designated as present. The data extraction and appraisal of the quality of studies were performed in duplicate by two teams of reviewers (AS and NA, HH and VJ).

\section{Data extraction}

The titles and abstracts identified by the electronic keywords search were printed and reviewed independently by two teams of independent reviewers to determine the relevance and whether the inclusion criteria were met. In case of disagreement or uncertainty regarding the relevance of the article, the full text was retrieved and analyzed. An abstraction sheet was prepared containing the title of the manuscript, author/date, year of study, age, location of the study conducted, sample size, aim of the study, experimental design, statistics used, odds ratio and $95 \%$ confidence interval, outcome and conclusions. Prior to commencement of the study, the full text of the relevant articles selected for this review was obtained. We separated the articles related to salivary cortisol as a measure of stress and studies focused on affective response. The studies that used a questionnaire to perceive stress were regarded as studies regarding affective response. 
In phase I of the electronic search, animal studies and studies related to oxidative and mechanical stress were excluded, and 43 suitable articles were selected. In phase II, the articles that had the potential to fulfill the inclusion criteria were evaluated in their full-text format to determine their quality and eligibility for inclusion. The reference lists were checked independently by the reviewers to identify other articles relevant to the research question that might have provided additional information. Any divergence regarding inclusion was discussed between the reviewers and resolved by the scientific advisor (AS). The selection of the study group, the quality of adjustment for confounding factors, adequate criteria to define periodontal disease and stress and the ascertainment of the outcome of interest were considered in inclusion of the articles.

\section{Results}

The initial search identified 309 articles because the terms periodontal disease and stress are relatively common terms in dental studies. Phase I identified 43 studies, which included 12 reviews and 6 articles related to biomarkers of stress and periodontal disease. These 18 articles were excluded in the second phase, which included 7 studies, predominantly because they did not have the exposure or outcomes required for this review; two of the studies were based on mental disorders and posttraumatic syndrome patients, respectively. A total of 18 potential articles were included in this systematic review.

\section{Description of the studies}

Twelve studies were cross-sectional[16,17,28-37], three were casecontrol [38-40] studies, one was a cohort study [41] and two were prospective clinical trial $[4,42]$ studies, comprising 5051 individuals. Two of the studies were conducted only with women [16,34], and two studies did not mention the gender distribution [29,31]. In most of the studies $[4,17,28-30,37,38,40-42]$, the participants were patients at a university periodontal clinic or private dental practice. Five studies $[31,33,35,36,41]$ were epidemiological surveys involving the residents in a particular area or a randomly selected general population. The study by Lopez et al. [39] was the only study that included students attending high school, which emphasized the relevance of assessing psychosocial stress and its association with periodontitis early in life. Two studies [16,32] involved patients from an academic institution, and one study involved women in the post-partum period [34].

\section{Criteria used to define periodontal disease}

All of the studies evaluated the periodontal pocket depth (PPD), and all, except for two studies, recorded bleeding on probing (BOP) $[17,29]$. Changes in the clinical attachment level (CAL) were evaluated by most of the studies; however, the study by Graetz et al.[42] used alveolar bone loss as the criterion for established periodontal disease. The plaque index and gingival index were recorded as additional clinical parameters in nine and four studies, respectively. Other criteria were the mobility of teeth as well as the recession level in five studies and the presence of calculus in two studies. Two of the 18 studies evaluated patients prospectively during periodontal therapy. Graetz et al., [42] in a 24-month prospective clinical trial, recorded the data on annual PPD and complete X-ray documentation at the baseline, at the end of the active periodontal treatment and at the last documented visit of the supportive periodontal therapy. Bakri et al.,[4] recorded the clinical parameters at the baseline and 6 months after non-surgical periodontal treatment. Only 6 studies reported intra- and/or inter-examiner calibration. In general, the majority of the studies used the Williams periodontal probe for periodontitis screening during oral health examinations. Two studies $[28,40]$ used the University of North Carolina \#15 periodontal probe, and one study each used the Michigan probe [17] and the Broke probe periodontal probe [37].

\section{Psychological measurements or affective response}

The affective response to psychological stress was demonstrated in all but one study [36] by using a psychometric measurement questionnaire. The Lipp Stress Symptoms Inventory questionnaire was used in two studies $[29,32]$. The other psychological parameters that were evaluated with the help of a questionnaire in the studies were as follows: perceived stress, depression, anxiety, social readjustment, general health issues, problems of everyday living, and experiences in close relationships, hopelessness, emotional intelligence, self-esteem, optimism, and satisfaction in life. The Visual Analog Scale was used as a measure of stress in a study by Johannsen et al.[16], and Spalj et al. [35] used a self-reported questionnaire to evaluate war stress. Two studies [37,41] validated and adapted the questionnaire for the study sample. Six studies, in addition to using questionnaires, used salivary cortisol levels as markers to evaluate stress, and two studies evaluated serum cortisol levels. The other stress markers used were salivary peptides, salivary enzymes, cytokine levels in gingival crevicular fluid and stress hormones.

\section{Control of confounding variables}

Adjustment of confounding variables is an important parameter in demonstrating the methodological quality of studies. The study designs minimize measurement biases affecting the dental and psychological assessment variables. The following investigations were conducted to determine whether the studies controlled various confounding variables. Randomization was followed at the design stage in one study [33]. All of the studies used exclusion criteria and achieved restriction. Nine studies performed stratification of the study sample as follows: Refulio et al. [28] (gender and smoking habits); Bakri et al. [4] and Forte et al. [32](stress exposure); three studies $[33,39,41]$ (age and race; Spalj et al. [35] (age and stress exposure); Ishisaka et al. [36] (smoking habits and race); and $\mathrm{Ng}$ et al. [37] (geographic location, high and low emotional copers). Five studies performed matching between the study groups as follows: Mousavijazi et al. [38] and Bakri et al. [4] matched for gender and smoking habits; Lopez et al. [39] matched for age, smoking habits and initial disease extent; Chiou et al. [33] performed matching for marital status and smoking habits; and Ishisaka et al. [36] matched for oral hygiene and preventive measures.

\section{Observations from the Cross Sectional Studies}

The cross control studies are summarized in Table 1. Out of the 18 studies 12 were case control studies. The study population varied in these studies from 20 to 1764 subjects. Cross-sectional studies revealed a clear-cut correlation between the progressive course of periodontal disease and the psychosocial stress status of patients. One study showed a lack of correlation between psychological stress and periodontal disease [32]. This study was performed among periodontally healthy subjects, and they concluded no influence of psychosocial stress on the salivary peptides that could predispose to periodontal disease. 
Citation: Halawany HS, Abraham NB, Jacob V, Al Amri MD, Patil S, et al. (2015) Is Psychological Stress a Possible Risk Factor for Periodontal Disease? A Systematic Review. J Psychiatry 18: 217. doi:10.4172/2378-5756.1000217

Page 4 of 7

\begin{tabular}{|c|c|c|c|c|c|c|}
\hline Author, Date, Country & Sample size & $\begin{array}{l}\text { Age group and } \\
\text { population }\end{array}$ & $\begin{array}{l}\text { Experime } \\
\text { ntal } \\
\text { design }\end{array}$ & Exposure to stress & Outcome & Critical appraisal and Conclusions \\
\hline $\begin{array}{l}\text { Refulio Z et al. [2013], } 28 \\
\text { Peru }\end{array}$ & $\begin{array}{l}70, \quad 36 \text { with } \\
\text { chronic } \\
\text { periodontitis } \\
\text { and } 34 \\
\text { without CP }\end{array}$ & $\begin{array}{l}30-65 \text { years, systemically } \\
\text { healthy subjects visiting a } \\
\text { teaching hospital }\end{array}$ & $\begin{array}{l}\text { cross- } \\
\text { sectional }\end{array}$ & $\begin{array}{l}\text { Affected response using } \\
\text { the Zung Self-rating, } \\
\text { Depression and Anxiety } \\
\text { Scale and salivary } \\
\text { cortisol }\end{array}$ & Positive & $\begin{array}{l}\text { Salivary cortisol and depression } \\
\text { showed an increased risk for chronic } \\
\text { periodontitis }\end{array}$ \\
\hline $\begin{array}{l}\text { Mannemand Chava, [2012] } \\
\text { [29] } \\
\text { India }\end{array}$ & $\begin{array}{l}111 \text { with and } \\
\text { without } \\
\text { chronic } \\
\text { periodontitis }\end{array}$ & $\begin{array}{l}\text { Below } 40 \text { years, Patients } \\
\text { who visited the periodontal } \\
\text { clinics }\end{array}$ & $\begin{array}{l}\text { cross- } \\
\text { sectional }\end{array}$ & $\begin{array}{l}\text { Affected response using } \\
\text { Lipp's Stress Symptoms } \\
\text { for Adults Inventory, and } \\
\text { salivary cortisol level }\end{array}$ & Positive & $\begin{array}{l}\text { Stress showed positive correlation to } \\
\text { periodontal disease }\end{array}$ \\
\hline $\begin{array}{l}\text { Rai et al., [2011] [30] } \\
\text { India }\end{array}$ & $\begin{array}{l}100 \text {, all with } \\
\text { periodontal } \\
\text { disease }\end{array}$ & $\begin{array}{l}40-56 \text { years, patients from } \\
\text { a periodontal clinic }\end{array}$ & $\begin{array}{l}\text { cross- } \\
\text { sectional }\end{array}$ & $\begin{array}{l}\text { Affected response using } \\
\text { the Derogate's Stress } \\
\text { Profile and salivary CgA, } \\
\text { cortisol, } \alpha \text { amylase and } B \\
\text { endorphin }\end{array}$ & Positive & $\begin{array}{l}\text { The stress and salivary stress markers } \\
\text { showed a positive correlation to } \\
\text { Periodontal disease }\end{array}$ \\
\hline $\begin{array}{l}\text { Goyal et al., [2011] [31] } \\
\text { India }\end{array}$ & $\begin{array}{l}47 \quad 16 \\
\text { chronic } \\
\text { periodontitis } \\
\text { subjects and } \\
31 \quad \text { stressed } \\
\text { subjects }\end{array}$ & 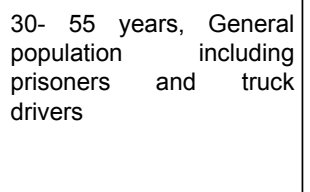 & $\begin{array}{l}\text { cross- } \\
\text { sectional }\end{array}$ & $\begin{array}{l}\text { Social readjustment } \\
\text { rating scale value of } \geq \\
149 \text { and the serum } \\
\text { cortisol level }\end{array}$ & Positive & $\begin{array}{l}\text { Psychosocial stress indicated by the } \\
\text { serum cortisol level was found to be a } \\
\text { contributing factor in the pathogenesis } \\
\text { of periodontal disease. }\end{array}$ \\
\hline $\begin{array}{l}\text { Chiou et al., [2010] [33] } \\
\text { Taiwan }\end{array}$ & $\begin{array}{l}1764 \text { subjects } \\
\text { with and } \\
\text { without } \\
\text { periodontitis }\end{array}$ & $\begin{array}{l}>18 \text { years, Respondents } \\
\text { of the Adults Oral Health } \\
\text { Survey }\end{array}$ & $\begin{array}{l}\text { cross- } \\
\text { sectional }\end{array}$ & $\begin{array}{l}\text { Affected response using } \\
\text { the Questionnaire to } \\
\text { assess the mental health }\end{array}$ & Positive & $\begin{array}{l}\text { Poor mental health had a stronger } \\
\text { association with periodontal disease }\end{array}$ \\
\hline $\begin{array}{l}\text { Forte et al., [2010] [32] } \\
\text { Brazil }\end{array}$ & $\begin{array}{l}90, \\
\text { Periodontally } \\
\text { healthy } \\
\text { subjects }\end{array}$ & $\begin{array}{l}22.6 \pm 3.4 \text { years, Army } \\
\text { students from the school } \\
\text { of Aeronautics }\end{array}$ & $\begin{array}{l}\text { cross- } \\
\text { sectional }\end{array}$ & $\begin{array}{l}\text { Affected response using } \\
\text { the Lipp's } \quad \text { Stress } \\
\text { Symptoms r and } \\
\text { antimicrobial peptides in } \\
\text { saliva }\end{array}$ & Negative & $\begin{array}{l}\text { Psychological stress does not have } \\
\text { any influence on the production of } \\
\text { salivary peptides and PD }\end{array}$ \\
\hline $\begin{array}{l}\text { Arteaga-Guerra et al., } \\
{[2010][34]} \\
\text { Colombia }\end{array}$ & $\begin{array}{l}46 \text { women, } \\
69.6 \% \text { had } \\
\text { periodontitis }\end{array}$ & $\begin{array}{l}18 \text { - } 34 \text { years, participants } \\
\text { were selected within } 48 \\
\text { hours of delivery in the } \\
\text { postpartum period. }\end{array}$ & $\begin{array}{l}\text { cross- } \\
\text { sectional }\end{array}$ & $\begin{array}{l}\text { Affected response using } \\
\text { the Spanish version of } \\
\text { the perceived stress test } \\
\text { questionnaire }\end{array}$ & Positive & $\begin{array}{l}\text { PD showed an association to } \\
\text { PTB, LBW and PLBW. It was linked to } \\
\text { physiological stress. }\end{array}$ \\
\hline $\begin{array}{l}\text { Johanssen et al., [2010] } \\
\text { [16] Sweden }\end{array}$ & 20 females & $\begin{array}{l}29.3 \pm 8.5 \text { years, Female } \\
\text { students in the 3rd year of } \\
\text { the dental hygienist } \\
\text { program }\end{array}$ & $\begin{array}{l}\text { cross- } \\
\text { sectional }\end{array}$ & $\begin{array}{l}\text { Affected response using } \\
\text { the Visual Analog Scale } \\
\text { and the measurement of } \\
\text { the salivary cortisol level } \\
\text { and cytokine levels. }\end{array}$ & Positive & $\begin{array}{l}\text { Academic stress appears to have an } \\
\text { effect on periodontal health }\end{array}$ \\
\hline $\begin{array}{l}\text { Rosania et al., [2009] [17] } \\
\text { USA }\end{array}$ & $\begin{array}{l}45, \text { All with } \\
\text { periodontal } \\
\text { disease }\end{array}$ & $\begin{array}{l}45-82 \text { years, recall } \\
\text { periodontal patients } \\
\text { referred by three dentists }\end{array}$ & $\begin{array}{l}\text { cross- } \\
\text { sectional }\end{array}$ & $\begin{array}{l}\text { Affected response using } \\
\text { Derogatis Stress Profile, } \\
\text { Centre for Epidemiologic } \\
\text { Studies depression } \\
\text { Scale. and Salivary } \\
\text { cortisol level }\end{array}$ & Positive & $\begin{array}{l}\text { Stress and depression may be } \\
\text { associated with periodontal } \\
\text { destruction. }\end{array}$ \\
\hline $\begin{array}{l}\text { Spalj et al., [2008] [35] } \\
\text { Croatia }\end{array}$ & $\begin{array}{l}282 \text {, Categori } \\
\text { zed as } \\
\text { healthy, BOP, } \\
\text { calculus, } \\
\text { periodontal } \\
\text { pocket depth }\end{array}$ & $\begin{array}{l}15-70 \text { years; Residents of } \\
\text { a former military occupied } \\
\text { village. }\end{array}$ & $\begin{array}{l}\text { cross- } \\
\text { sectional }\end{array}$ & $\begin{array}{l}\text { Affected response using } \\
\text { a self-administered } \\
\text { questionnaire based on } \\
\text { war stress, was in war, } \\
\text { refugee or lost or have a } \\
\text { wounded dear ones. }\end{array}$ & Positive & $\begin{array}{l}\text { Specific socio-economic and } \\
\text { psychologicalconditions in post-war } \\
\text { areas could be significant risk factors } \\
\text { for poor periodontal conditions. }\end{array}$ \\
\hline $\begin{array}{l}\text { Ishisaka et al.,[2008] [36] } \\
\text { Japan }\end{array}$ & $\begin{array}{l}467 \text {, Based on } \\
\text { the severity of } \\
\text { periodontitis }\end{array}$ & Older Japanese adults & $\begin{array}{l}\text { cross- } \\
\text { sectional }\end{array}$ & $\begin{array}{llr}\text { stress } & \text { level determined } \\
\text { from blood } & \text { samples } \\
\text { serum } & \text { cortisol/ } & \text { DHEAS } \\
\text { levels } & & \end{array}$ & positive & $\begin{array}{l}\text { There were significant associations } \\
\text { between serum cortisol level, including } \\
\text { cortisol/DHSEAS ratio, and } \\
\text { periodontitis severity in elderly } \\
\text { subjects. }\end{array}$ \\
\hline $\begin{array}{l}\mathrm{Ng} \text { et al., [2006] [37] Hong } \\
\text { Kong }\end{array}$ & 1000 General, & $\begin{array}{l}\text { Patients visiting three } \\
\text { general dental practices }\end{array}$ & $\begin{array}{l}\text { Cross- } \\
\text { sectional }\end{array}$ & $\begin{array}{lll}\text { Affected } & \text { response } & \text { using } \\
\text { the } & \text { Life } & \text { Event }\end{array}$ & Positive & $\begin{array}{l}\text { Chronic job and financial strains, } \\
\text { depression, inadequate coping, and } \\
\text { maladaptive trait dispositions are }\end{array}$ \\
\hline
\end{tabular}




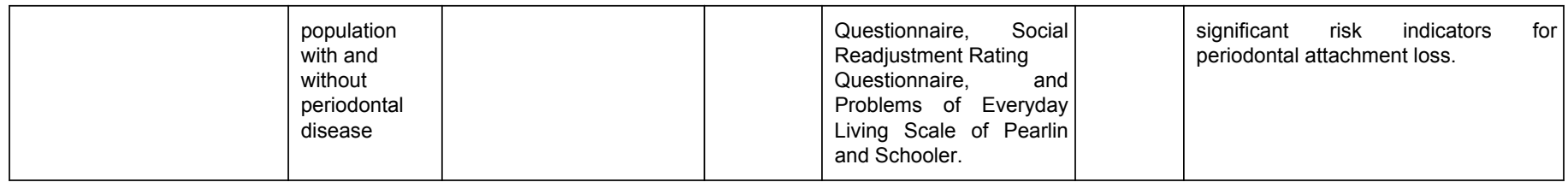

Table 1: Cross sectional studies showing relationship between stress and periodontal disease

\section{Observations from the Case-Control Studies}

Three case control studies were included in this review. All the three studies [38-40] showed a positive correlation between periodontal problems and stress. One study reported a negative outcome. Three studies (16.7\%) observed a partially positive outcome, and the remaining two studies (11.11\%) found an indirect association between stress and periodontal disease. Dumitrescu and Kawamura [40] performed a case control study of 79 subjects between the ages of 19 to 69 yr. old and obese subjects. Periodontal examination was assessed and the subjects were asked to complete a set of questionnaires measuring Type A personality, anxiety, depression, dental anxiety, hopelessness, emotional intelligence, stress, self-esteem, optimism and satisfaction with life. Multiple linear regression analyses of the data revealed that stress and anxiety was positively associated with the number of teeth with a PD of $>6 \mathrm{~mm}$. it was concluded that that there is an association between several psychological determinants, periodontitis, and body mass index. Lopez et al. [39] studied the psychosocial distress and periodontitis among 160 adolescents. The periodontitis inclusion criterion used is the clinical attachment level of $>=3 \mathrm{~mm}$ in at least two teeth. Stress was assessed using a 28 item Spanish version of health questionnaire. Multiple logistic regression analyses were used to assess the association between periodontitis and psychosocial distress. They found that an association between periodontitis and dimensions of psychosocial distress is evident among the adolescent population.

The association between psychological stress and elevation of inflammatory mediators related to periodontal disease in adult patient were evaluate in 25 patients with chronic periodontitis and 25 cases with aggressive periodontitis and 25 healthy subjects [38]. The Kettle stress questionnaire was also used to determine stress severity. . The clinical parameters including plaque index (PI), bleeding on probing (BOP), probing depth (PPD) and clinical attachment loss (CAL) were recorded and IL- 6 and IL-1beta levels of the GCF was estimated. They concluded that psychological stress has a pivotal role in the stimulation of inflammatory processes via IL-1beta increase in aggressive and chronic periodontitis.

\section{Observations from Other Studies}

A longitudinal study was conducted by Graetz et al. [42] to find out the associations between attachment patterns and periodontal parameters among 310 patients with aggressive $(\mathrm{AgP})$ and chronic periodontitis (CP).They concluded that psychological attachment patterns are a promising target for understanding periodontal disease in addition to known psychosocial risk factors. Stress alters the production of pro inflammatory cytokines, causing substantial delay in wound healing and treatment outcome [43]. Bakri et al. [4] conducted a longitudinal study on the effects of stress on periodontal treatment outcome using clinical and biological markers. They found that patients under psychosocial stress had a poorer outcome following non-surgical periodontal therapy. The oral health status of the immigrants from Ethiopia to Israel were studied by Vered et al. [41]. The periodontal health status was recorded employing the Community Periodontal Index (CPI). A structured written questionnaire which included two validated psychosocial scales, for psychological distress and social support were used to assess the perceived stress. Multivariate analyses of the data showed positive evidence of the role of psychological distress and social support as determinants of changing oral health levels.

\section{Discussion}

Periodontitis is an inflammatory response of the periodontium which involves the destruction of the investing tissues around the teeth, resulting in loss of tooth support, ultimately leading to the tooth loss. The pathogenic processes of the periodontal diseases are largely the results of the host response to microbially induced tissue destruction. The microbes induce destruction of periodontal tissues by initiating inflammatory and immune responses by various inflammatory molecules such as proteases, cytokines, prostaglandins and host enzymes released from leukocytes and fibroblasts [44]. Many studies have shown the important role of microbial pathogenesis in periodontitis; however, bacteria alone appear to be insufficient in explaining the progression of the disease [45]. Age, tobacco smoking, genetic factors, socioeconomic status, systemic diseases and psychological stress have been identified as additional risk factors for periodontitis $[9,46]$.

This review aimed to systematically aggregate and critically appraise the substantial literature on the influence of psychological stress as a risk factor for periodontal disease. The use of methodological filters of human studies in English to address the association of two major conditions including psychological stress and periodontal disease increased the title and abstract specificity of the search strategy. Two teams of independent reviewers performed the screening in duplicate, which might have enhanced the study selection and evaluation process. In general, the analysis of the studies revealed a positive association between stress and periodontal disease. Unlike the previous review by Peruzzo et al. [9], we identified one cohort study [41] that suggested persuasive evidence of psychological distress and social support as risk factors. The positive association was derived predominantly from prospective clinical trial [42], cross-sectional $[16,17,28-31,33,37]$ and case-control studies [38-40]. One crosssectional study by Forte et al. [32] did not reproduce a positive finding.

In the 18 studies, the methodological approaches were quite variable, and it was impossible to accurately summarize the evidence for the association between a unique and well-defined characterization of exposure to stressors and the incidence of periodontal disease. The variation in the studies involved the type of periodontal disease evaluated, the parameters used to measure periodontal status, the type of psychosocial factor assessed, the type of questionnaire used and the 
potential control of various confounding variables. A large number of instruments are used to measure the affective response of stress and the use of cortisol as a measure to determine stress but its association with periodontitis is not well established. The instruments to measure stress vary widely because of the many different dimensions of psychosocial distress, and it is unlikely that these dimensions similarly affect periodontal diseases. This might have a bias in the observation from these studies and may be one of the limitation of the outcome measure.

Periodontitis is a highly prevalent disease, and it is extremely challenging to control the potential confounding variables such as age, gender, sample size, smoking habits, diabetes, systemic illness, educational level, socioeconomic status, allocation concealment, and calibration. We attempted to determine the quality of the studies based on randomization, stratification, restriction, calibration, statistical modeling, and/ or matching, by which each study controlled the confounding variables. In the evaluated studies, the following criteria were used to define periodontal disease: PPD, BOP, CAL, ABL, REC, the presence of calculus, plaque, and mobility of teeth. Comparison of observations of the study was difficult because of the heterogeneity of the parameters used by researchers to assess active periodontitis. The biological mechanism behind the association between periodontal health and psychosocial factors might be related to the possibility that stress modifies the immune response, regulates other responses to periodontopathic microbes, changes the gingival circulation and produces hormonal changes [10,47], all of which might cause an imbalance in the immune system, leading to the breakdown of the microenvironment equilibrium and resulting in the development of periodontal disease [48]. The use of psychological intervention as adjunct measure in the treatment of periodontal disease might deserve further evaluation.

\section{Conclusions}

This report attempted to find evidence on the relationship between stress and periodontal disease.Psychological disturbances have been shown to affect the progression of periodontal disease and the response to periodontal therapy. Majority of the studies showed that stress has an influence on periodontal disease development and treatment outcomes. High-quality studies are needed that would demonstrate the effect of psychological factors or stress as a potential risk factor for periodontal disease.

\section{References}

1. Petersen PE (2003) The World Oral Health Report 2003: continuous improvement of oral health in the 21st century--the approach of the WHO Global Oral Health Programme. Community dentistry and oral epidemiology 31 Suppl 1: 3-23.

2. Graves D, Li J, Cochran D (2011) Inflammation and uncoupling as mechanisms of periodontal bone loss. Journal of dental research 90:143-153.

3. Li X, Kolltveit KM, Tronstad L, Olsen I (2000) Systemic diseases caused by oral infection. Clin Microbiol Rev 13: 547-558.

4. Bakri I, Douglas CW, Rawlinson A (2013) The effects of stress on periodontal treatment: a longitudinal investigation using clinical and biological markers. Journal of clinical periodontology 40: 955-961.

5. Vettore MV, Leao AT, Monteiro Da Silva AM, Quintanilha RS, Lamarca GA (2003) The relationship of stress and anxiety with chronic periodontitis. Journal of clinical periodontology 30: 394-402.

6. Vettore M, Quintanilha RS, Monteiro da Silva AM, Lamarca GA, Leao AT (2005) The influence of stress and anxiety on the response of non- surgical periodontal treatment. Journal of clinical periodontology 32 : 1226-1235.

7. Preeja C, Ambili R, Nisha KJ, Seba A, Archana V (2013) Unveiling the role of stress in periodontal etiopathogenesis: an evidence-based review. Journal of investigative and clinical dentistry 4: 78-83.

8. Meyer MJ (1989) Stress and periodontal disease: a review of the literature. Journal of the New Zealand Society of Periodontology 68: 23-26.

9. Peruzzo DC, Benatti BB, Ambrosano GM, Nogueira-Filho GR, Sallum EA, et al. (2007) A systematic review of stress and psychological factors as possible risk factors for periodontal disease. Journal of periodontology 78: 1491-1504.

10. Peruzzo DC, Benatti BB, Antunes IB, Andersen ML, Sallum EA, et al. (2008) Chronic stress may modulate periodontal disease: a study in rats. Journal of periodontology 79: 697-704.

11. Boyapati L, Wang HL (2007) The role of stress in periodontal disease and wound healing. Periodontology 44: 195-210.

12. LeResche L, Dworkin SF (2002) The role of stress in inflammatory disease, including periodontal disease: review of concepts and current findings. Periodontology 30: 91-103.

13. Genco RJ, Ho AW, Grossi SG, Dunford RG, Tedesco LA (1999) Relationship of stress, distress and inadequate coping behaviors to periodontal disease. Journal of periodontology 70: 711-723.

14. Monteiro da Silva AM, Oakley DA, Newman HN, Nohl FS, Lloyd HM (1996) Psychosocial factors and adult onset rapidly progressive periodontitis. Journal of clinical periodontology 23: 789-794.

15. Moss ME, Beck JD, Kaplan BH, Offenbacher S, Weintraub JA, et al. (1996) Exploratory case-control analysis of psychosocial factors and adult periodontitis. Journal of periodontology 67: 1060-1069.

16. Johannsen A, Bjurshammar N, Gustafsson A (2010) The influence of academic stress on gingival inflammation. International journal of dental hygiene 8: 22-27.

17. Rosania AE, Low KG, McCormick CM, Rosania DA (2009) Stress, depression, cortisol, and periodontal disease. Journal of periodontology 80: 260-266.

18. Rosenkranz MA (2007) Substance P at the nexus of mind and body in chronic inflammation and affective disorders. Psychol Bull 133: 1007-1037.

19. Hamaguchi T, Fukudo S, Kanazawa M, Tomiie T, Shimizu K, et al. (2008) Changes in salivary physiological stress markers induced by muscle stretching in patients with irritable bowel syndrome. Biopsychosoc Med 2: 20.

20. Sanders VM, Straub RH (2002) Norepinephrine, the beta-adrenergic receptor, and immunity. Brain, behavior, and immunity 16: 290-332.

21. Helle KB (2010) Regulatory peptides from chromogranin A and secretogranin II. Cell Mol Neurobiol 30: 1145-1146.

22. Lima DP, Diniz DG, Moimaz SA, Sumida DH, Okamoto AC (2010) Saliva: reflection of the body. Int J Infect Dis 14: e184-188.

23. Rohleder N, Nater UM (2009) Determinants of salivary alpha-amylase in humans and methodological considerations. Psychoneuroendocrinology 34: 469-485.

24. Lundy FT, Linden GJ (2004) Neuropeptides and Neurogenic Mechanisms in Oral and Periodontal Inflammation. Crit Rev Oral Biol Med 15: 82-98.

25. Kiecolt-Glaser JK, Preacher KJ, MacCallum RC, Atkinson C, Malarkey WB, et al. (2003) Chronic stress and age-related increases in the proinflammatory cytokine IL-6. Proceedings of the National Academy of Sciences of the United States of America 100: 9090-9095.

26. Schneider G, Leyendecker SS (2004) [Correlation between psychosocial factors and periodontal disease--a systematic review of the literature]. Zeitschrift fur Psychosomatische Medizin und Psychotherapie 51: 277-296.

27. NHS. Centre for Reviews and Dissemination. Undertaking systematic Reviews of research on effectiveness. CRD's guidance for those carrying out or commissioning reviews. 
Citation: Halawany HS, Abraham NB, Jacob V, Al Amri MD, Patil S, et al. (2015) Is Psychological Stress a Possible Risk Factor for Periodontal Disease? A Systematic Review. J Psychiatry 18: 217. doi:10.4172/2378-5756.1000217

Page 7 of 7

28. Refulio Z, Rocafuerte M, de la Rosa M, Mendoza G, Chambrone L (2013) Association among stress, salivary cortisol levels, and chronic periodontitis. Journal of periodontal \& implant science 43: 96-100.

29. Mannem S, Chava VK (2012) The effect of stress on periodontitis: A clinicobiochemical study. Journal of Indian Society of Periodontology 16 : 365-369.

30. Rai B, Kaur J, Anand SC, Jacobs R (2011) Salivary stress markers, stress, and periodontitis: a pilot study. Journal of periodontology 82: 287-292.

31. Goyal S, Jajoo S, Nagappa G, Rao G (2011) Estimation of relationship between psychosocial stress and periodontal status using serum cortisol level: a clinico-biochemical study. Indian journal of dental research : official publication of Indian Society for Dental Research 22: 6-9.

32. Forte LF, Cortelli SC, Cortelli JR, Aquino DR, de Campos MV, et al (2010) Psychological stress has no association with salivary levels of betadefensin 2 and beta-defensin 3. Journal of oral pathology \& medicine : official publication of the International Association of Oral Pathologists and the American Academy of Oral Pathology 39: 765-769.

33. Chiou LJ, Yang YH, Hung HC, Tsai CC, Shieh TY et al. (2010) The association of psychosocial factors and smoking with periodontal health in a community population. Journal of periodontal research 45: 16-22.

34. Arteaga-Guerra JJ, Ceron-Souza V, Mafla AC (2010) Dynamic among periodontal disease, stress, and adverse pregnancy outcomes. Revista de salud publica (Bogota, Colombia) 12: 276-286.

35. Spalj S, Plancak D, Bozic D, Kasaj A, Willershausen B, et al. (2008) Periodontal conditions and oral hygiene in rural population of post-war Vukovar region, Croatia in correlation to stress. European journal of medical research 13: 100-106.

36. Ishisaka A, Ansai T, Soh I, Inenaga K, Awano S, et al. (2008) Association of cortisol and dehydroepiandrosterone sulphate levels in serum with periodontal status in older Japanese adults. Journal of clinical periodontology 35: 853-861.

37. Ng SK, Leung KW (2006) A community study on the relationship between stress, coping, affective dispositions and periodontal attachment loss. Community dentistry and oral epidemiology 34: 252-266.
38. Mousavijazi M, Naderan A, Ebrahimpoor M, Sadeghipoor M (2013) Association between psychological stress and stimulation of inflammatory responses in periodontal disease. Journal of dentistry (Tehran, Iran) 10: 103-111.

39. Lopez R, Ramirez V, Marro P, Baelum V (2012) Psychosocial distress and periodontitis in adolescents. Oral health \& preventive dentistry 10: 211-218.

40. Dumitrescu AL, Kawamura M (2010) Involvement of psychosocial factors in the association of obesity with periodontitis. Journal of oral science 52: 115-124.

41. Vered Y, Soskolne V, Zini A, Livny A, Sgan-Cohen HD (2011) Psychological distress and social support are determinants of changing oral health status among an immigrant population from Ethiopia. Community dentistry and oral epidemiology 39: 145-153.

42. Graetz C, Ehrenthal JC, Senf D, Semar K, Herzog W, et al. (2013) Influence of psychological attachment patterns on periodontal disease-a pilot study with 310 compliant patients. Journal of clinical periodontology 40: 1087-1094.

43. Glaser R, Kiecolt-Glaser JK (2005) Stress-induced immune dysfunction: implications for health. Nature reviews. Immunology 5: 243-251.

44. Gemmell E, Marshall RI, Seymour GJ (1997) Cytokines and prostaglandins in immune homeostasis and tissue destruction in periodontal disease. Periodontology 14: 112-143.

45. Leininger M, Tenenbaum H, Davideau JL (2010) Modified periodontal risk assessment score: long-term predictive value of treatment outcomes. A retrospective study. Journal of clinical periodontology 37: 427-435.

46. Cronin AJ, Claffey N, Stassen LF (2008) Who is at risk? Periodontal disease risk analysis made accessible for the general dental practitioner. British dental journal 205: 131-137.

47. Breivik T, Thrane PS, Murison R, Gjermo P (1996) Emotional stress effects on immunity, gingivitis and periodontitis. European journal of oral sciences 104: 327-334.

48. Linden GJ, Mullally BH, Freeman R (1996) Stress and the progression of periodontal disease. Journal of clinical periodontology 23: 675-680. 